University of Louisville

ThinkIR: The University of Louisville's Institutional Repository

\title{
"A more perfect union" : exploring the nature and terms of the American Union.
}

Meghan A. Waters

University of Louisville

Follow this and additional works at: https://ir.library.louisville.edu/honors

Part of the American Politics Commons, and the Political Theory Commons

\section{Recommended Citation}

Waters, Meghan A., "'A more perfect union" : exploring the nature and terms of the American Union." (2014). College of Arts \& Sciences Senior Honors Theses. Paper 75.

http://doi.org/10.18297/honors/75

This Senior Honors Thesis is brought to you for free and open access by the College of Arts \& Sciences at ThinkIR: The University of Louisville's Institutional Repository. It has been accepted for inclusion in College of Arts \& Sciences Senior Honors Theses by an authorized administrator of ThinkIR: The University of Louisville's Institutional Repository. This title appears here courtesy of the author, who has retained all other copyrights. For more information, please contact thinkir@louisville.edu. 
"A More Perfect Union":

Exploring the Nature and Terms of the American Union

By

Meghan A. Waters

Submitted in partial fulfillment of the requirements

for Graduation summa cum laude

University of Louisville

May, 2014 
"I hold that in contemplation of universal law and of the Constitution the Union of these States is perpetual. Perpetuity is implied, if not expressed, in the fundamental law of all national governments. It is safe to assert that no government proper ever had a provision in its organic law for its own termination. Continue to execute all the express provisions of our National Constitution, and the Union will endure forever, it being impossible to destroy it except by some action not provided for in the instrument itself."

-Abraham Lincoln, First Inaugural Address, March 4, 1861

"[I]f they will break us up - in God's name, let the Union go. I love the Union as I love my wife. But if my wife should ask and insist upon a separation, she should have it, though it broke my heart."

-John Quincy Adams, 1801

"I pledge allegiance to the flag of the United States of America, and to the republic for which it stands, one nation, under God, indivisible, with liberty and justice for all." The Pledge of Allegiance to the United States flag perfectly captures several of the values Americans hold most dear: liberty, equality in the eyes of the law, and national unity. American history demonstrates, however, that national unity was not always such a universal value. The possibility of disunion and the question of secession have surfaced several times in the history of the United States (for example, during the War of 1812, the Nullification Controversy of 1832, and the Civil War). These threats of disunion relied on a certain understanding of the American Union in which secession is a permissible way for states to resolve constitutional wrongs, an idea that seems foreign to most Americans today. Since the act of secession is incompatible with the idea of an indissoluble Union, it is necessary to turn to the founding documents and debates for more insight into these two interpretations of the American Union.

A careful study of the founding period reveals two dominant and competing understandings of the structure of the new nation: one espousing a compact theory of the Union and another advocating for a nationalist theory. The compact theory maintains that each state is a sovereign, political body. These separate, sovereign states convened to form the central 
government of the United States, delegating some of their sovereignty to the central government for their own safety and the common good. Because the central government is a creature of the states, they may challenge, limit, and/or rescind the state sovereignty that was transferred to the central government in the original contract. Nationalist theory, on the other hand, insists that the states are not sovereign entities. Rather, nationalists contend that, after our separation from Great Britain, the people of the United States came together as a whole and formed the central government, which then created the several states. In other words, the Union created the states, not vice versa, as the compact theory claims. Thus, under the nationalist understanding, the states have no authority to challenge or renounce the national government since they were created through its power. ${ }^{1}$

Both of these theories regarding the nature of the Union had their supporters at the founding period. However, after President Abraham Lincoln's strong nationalist rhetoric and the bloody war that enforced this nationalist vision, the compact theory virtually disappeared from mainstream American political thought. Still, if, as several scholars still contend, the compact theory of the Union had many important supporters at the time of the American founding, should a constitutional disagreement with such a pedigree be resolved in bloodshed? Pulitzer Prize winning historian Jack Rakove may have gotten it correct when he stated: "[t]o reduce or equate the validity of secession with the course of war would convert a basic problem of constitutional governance into a matter of military fate.", In the pages that follow, I search the records of the

\footnotetext{
${ }^{1}$ Donald Livingston, "The Founding and the Enlightenment: Two Theories of Sovereignty," in Vital Remnant: America's Founding and the Western Tradition, ed. by Gary L. Gregg II (Wilmington: ISI Books, 1999), $255-257$. 2 Jack N. Rakove, “'A Real Nondescript': James Madison's Thoughts on States' Rights and Federalism," in Union and States' Rights: A History and Interpretation of Interposition, Nullification, and Secession 150 Years After Sumter, ed. by Neil H. Cogan (Akron: University of Akron Press, 2014), 15.
} 
founding period for evidence of the compact theory of the Union and its remedy of last resort, secession.

\section{$\underline{\text { Methodology }}$}

My objective is to find and assess evidence from the founding period that lends support to the compact theory of the Union and secession. To be clear, the question at hand is not whether secession is prudent. My concern is not whether secession should be encouraged today or at any time in American history. Nor is my objective to establish a definitive understanding of the Constitution and the American Union. Rather, I only seek to investigate one interpretation of the Union that has been largely disregarded in recent history. In my attempt to evaluate this particular understanding of the American Union, I have consulted the core primary texts from the period, including The Federalist Papers, the records from the Constitutional Convention of 1787, and the subsequent state ratifying conventions. I have also consulted the papers and speeches of many of the Founding Fathers, including Thomas Jefferson and James Madison. Additionally, I have consulted the works of notable experts in the study of the founding period who have taken up the topics related to my research, including Allen Buchanan, Donald Livingston, and Kenneth Stampp. My goal is to provide a better understanding of the compact nature of the American Union and shed new scholarly light on the resurgent discussion of secession and "states' rights" in America today.

\section{$\underline{\text { Definition of Terms and Concepts }}$}

As with any research question, it is necessary to define the terms and concepts related to this query. Before evaluating the compact theory of the American Union and the question of secession, I will define the term "secession," as well as describe the nationalist and compact 
theories of our Union in more detail. Then, I will examine the intersection between the act of secession and the compact theory of the American Union.

\section{What is Secession?}

Let me begin with the proper definition and origins of the term "secession." According to political scientist H. Lee Cheek, "the verb 'to secede' is derived from the Latin secedere meaning 'to withdraw' and referring to any act of withdrawal." 3 Donald Livingston of Emory University explains that before the term "secession" was strictly associated with political theory, "one could speak of the soul seceding from the body; or of seceding from one room of a building to another; or of seceding from any sort of human fellowship." This is how 'secession' was defined in Samuel Johnson's Dictionary in the mid-eighteenth century, Livingston says. ${ }^{4}$ The division of the Church of Scotland in 1733 helped incorporate the idea of secession into the body of political theory. People who left the Church of Scotland were known as "seceders," and their new Church was called the "Secession Church." As Livingston states, "[t]he seceding selfgoverning religious community paved the way for the seceding self-governing political community and the term as we understand it today." In contemporary usage the word "secession" almost exclusively refers to a political act. Our understanding of the term "presupposes the background of the modern state, and this sort of state is only about two centuries old. So secession is not just any kind of political action; it is the withdrawal of a people

\footnotetext{
${ }^{3}$ H. Lee Cheek, Jr., "Secession," in Encyclopedia of the American Civil War: A Political, Social, and Military History, ed. by David S. Heidler et al. (Santa Barbara: W.W. Norton and Company, 2002), 1718. ${ }^{4}$ Donald W. Livingston, "The Secession Tradition in America," in Secession, State and Liberty, ed. by David Gordon (New Brunswick: Transaction Publishers, 1998), 1.

${ }^{5}$ Ibid., 1-2.
} 
from a modern state under the moral principle of the right of self-government, and such that the separation requires the territorial dismemberment of that state." 6

Historically, political philosophy remains largely silent on the issue of secession. Duke University professor Allen Buchanan, one of the leading experts in secession, observes: "Neither Plato, Hobbes, Locke, Rousseau, Hegel, Marx, nor Mill devoted any serious attention to secession."7 There are plenty of discussions regarding other forms of political resistance, such as revolution and civil disobedience, but little to no attention is paid to secession. In his landmark work Secession: The Morality of Political Divorce from Fort Sumter to Lithuania and Quebec, Buchanan seeks to fill this gap in political philosophy. He begins by introducing secession as a form of political resistance and comparing secession to other types of resistance, namely, revolution and civil disobedience. Buchanan explains:

Unlike the revolutionary, the secessionist's primary goal is not to overthrow the existing government, nor to make fundamental constitutional, economic, or sociopolitical changes within the existing state. Instead, she wishes to restrict the jurisdiction of the state in question so as not to include her own group and the territory it occupies. The salient distinction between secession and revolution is that successful secession, being aimed only at restricting the scope of the state's power, not dissolving it, does not, like revolution, require (though it may in fact result in) the overthrow of the government. ${ }^{8}$

Thus, secessionists intend to leave the existing government as is and only wish to limit its authority over their territory. Like secessionists, civil disobedients do not intend to overthrow the existing government and largely recognize its authority as legitimate. As Buchanan points out, "through deliberately and openly violating some law or laws, he [the civil disobedient] opposes

\footnotetext{
${ }^{6}$ Livingston, "Secession Tradition," 2.

${ }^{7}$ Allen Buchanan, Secession (Boulder: Westview Press, Inc., 1991), vii.

${ }^{8}$ Ibid., 10.
} 
certain policies or activities of the government, and he does so on ground of political morality." Buchanan also notes that these actions of civil disobedience can sometimes lead to secession, as in the case of Gandhi's civil disobedience aimed at India's secession from the British Empire. ${ }^{10}$

In the American context, the principle of secession assumes a certain understanding of our Union where the states have the authority to challenge, abandon, and/or dissolve the central government. Let us turn, then, to the two dominant understandings of the Union and what they might mean for questions related to secession.

Nationalist Theory versus Compact Theory: Two Understandings of the American Union As I mentioned above, scholars usually divide the American founding debates regarding the nature of our Union into two major intellectual camps: nationalist theorists and compact theorists. Each theory contains fundamental assumptions about the American Union:

\section{Nationalist Theory}

-States are not sovereign political bodies.

-The national government created the states as its agents.

-States do not have the authority to challenge or dissolve the authority of the national government.
Compact Theory

-States are sovereign political bodies -States created the national government through a compact with one another. -States may challenge or dissolve the authority of the national government.

As shown in the above table, one of the main differences between the two theories is the question of the locus of sovereignty. While the compact theory acknowledges that the states are independent, sovereign entities, the nationalist theory asserts that the states are mere agents of the federal government, liaisons, if you will, between the central government and the people.

\footnotetext{
${ }^{9}$ Buchanan, Secession, 10.

${ }^{10}$ Ibid.
} 
According to the compact theory, the states possess absolute sovereignty, may question the powers of the national government and, if need be, recall the sovereignty they delegated to the national government. On the other hand, the nationalist theory maintains that the states are the political creations of the national government and, thus, have no authority to challenge its authority or its existence. ${ }^{11}$

Before further examining the American founding in light of the compact theory, it is important to place the terms "compact" and "contract" and their implications in historical context. ${ }^{12}$ Traditionally in Anglo-American jurisprudence, "[a] contract is a promise, or set of promises, for the breach of which the law gives a remedy, or the performance of which the law in some way recognizes as a duty. Synonyms for the term 'contract' are 'agreement' and 'compact." ${ }^{, 13}$ In order to create a contract, at least two parties must assent to fulfill certain obligations in an agreement. If one party breaches the terms outlined in the agreement, the other party has the right to take legal action against the delinquent party. According to Kentucky attorney and documentary film producer Kent Masterson Brown, "[a] 'breach' of a contract is simply a failure on the part of one or more of the contracting parties, without legal excuse, to perform any promise that forms the whole or part of the contract." ${ }^{14}$ In Anglo-American law there are several legal remedies one can pursue for breach of contract. First, the injured party can take their case to court and seek monetary restitution for damages incurred from the breach of

\footnotetext{
${ }^{11}$ Donald Livingston, "Introduction: The Old Assumptions No Longer Apply," in Rethinking the American Union for the Twenty-First Century, ed. by Donald Livingston (Gretna: Pelican Publishing Company, 2012), 23.

${ }^{12}$ N.B. As they are synonyms, I will use the terms "compact" and "contract" interchangeably.

${ }^{13}$ Kent Masterson Brown, "Secession: A Constitutional Remedy that Protects Fundamental Liberties," in Rethinking the American Union for the Twenty-First Century, ed. by Donald W. Livingston (Gretna: Pelican Publishing Company, 2012), 34.

14 Ibid.
} 
contract. Second, the aggrieved party can petition the court to force the other party to fulfill their contractual obligations, or else find themselves in contempt of court. The last remedy for breach of contract is "'rescission,' or the annulment of the contract... The aggrieved party can ask the court to annul the contract and, at the same time, ask that he be made whole for his own performance, thereby placing him in the same position he occupied before he entered into the contract."15

If evidence suggests that the Articles of Confederation and the Constitution could be viewed as contracts (or compacts) between sovereign states, then these documents could be interpreted in the context of Anglo-American contract law. As parties to these contracts, then, "the States have the equitable right of rescission in the event of a breach of the agreement.",16 Thus, secession would be justifiable if the Articles and the Constitution can be interpreted as contracts. To begin evaluating these claims, I will first turn to principles of government that emerged out of the American Revolution.

\section{The American Revolution: America's First Secession}

At this juncture, it is important to consider Buchanan's discussion of the terms "secession" and "revolution" in the context of the American founding. From the outset of the Revolutionary War, the American colonists never had any intention of overthrowing the British government on British soil. They were not traditional revolutionaries, at least not according to Buchanan's definition of the term. They did not question the rule of Parliament or the role of the King on the soil of the United Kingdom. Their goal was simply to separate from the British

\footnotetext{
${ }^{15}$ Brown, "Secession: A Constitutional Remedy," 34-35.

${ }^{16}$ Ibid., 35.
} 
Empire and retain the territory in the New World under their own rule. Thus the American

"Revolution" was not a "revolution" in the traditional sense at all; it was a form of secession.

A look at the foundational document of the American War for Independence points to

that war as a type of secession movement: one people breaking their political bonds with another

and declaring their independence and the causes "which impel them to the separation."

When, in the course of human events, it becomes necessary for one people to dissolve the political bonds which have connected them to another, and to assume, among the powers of the earth, the separate and equal station to which the laws of nature and of nature's God entitle them, a decent respect to the opinions of mankind requires that they should declare the causes which impel them to the separation.

We hold these truths to be self-evident: that all men are created equal; that they are endowed, by their Creator, with certain unalienable rights; that among these rights are life, liberty, and the pursuit of happiness. That to secure these rights, governments are instituted among men, deriving their just powers from the consent of the governed; that whenever any form of government becomes destructive of these ends, it is the right of the people to alter or abolish it, and to institute new government, laying its foundation on such principles, and organizing its powers in such form, as to them shall seem most likely to affect their safety and happiness... [W] hen a long train of abuses and usurpations...evinces a design to reduce them under absolute despotism, it is their right, it is their duty, to throw off such government, and to provide new guards for their future security. ${ }^{17}$

The idea of one part of a nation separating from the rest of the nation by a type of secession, then, seems present in American political thought from our very beginnings, as evidenced by the Declaration of Independence. David Gordon, a senior fellow at the Mises Institute, goes so far as to assert that "[ $\mathrm{t}]$ he right of secession lies at the heart of our country's legitimacy. Deny it, and you must reject the American founding." ${ }^{18}$ It seems, however, that this understanding of the American experience has been lost or disregarded over the course of the last two centuries. Thus,

\footnotetext{
${ }^{17}$ Declaration of Independence (1776).

${ }^{18}$ David Gordon, Introduction to Secession, State and Liberty, ed. by David Gordon (New Brunswick: Transaction Publishers, 1998), ix.
} 
we must return to the documents and writings of the founding period to better understand an interpretation of the American Union that has largely been forgotten.

\section{The Articles of Confederation: A Contract between the States?}

As mentioned, the principle of secession assumes a certain understanding of our Union where the states have the authority to challenge, abandon, and/or dissolve the central government. In the American context, this understanding of the Union is best illustrated by the compact theory. If, then, our founding documents can be situated in the context of the compact theory and Anglo-American contract law, secession can be understood as an acceptable remedy for a breach of these contracts. If not, then secession would find no such support.

In order for the Articles of Confederation to be considered in terms of the compact theory and Anglo-American contract law, there are three conditions that must be met. First, the states must be considered sovereign political bodies. Second, the founders must have recognized the Articles of Confederation as a contract. And lastly, the sovereign states must be the parties to this contract.

\section{Colonial and State Sovereignty}

The sovereignty of the thirteen original colonies has been the topic of much debate throughout American history. But research indicates that the sovereignty of the states (or future states) was established even before the colonies' secession from Great Britain. Historian Nathan Coleman chronicles the changes in the political environment of the British crown and the American colonies. He asserts that a kind of "imperial federalism" had developed between the American colonies and the British crown by the mid- $18^{\text {th }}$ century, where both Parliament and the 
colonies exercised sovereignty over certain affairs. Parliament and the King conducted external affairs affecting the colonies, such as international relations, while the colonies themselves handled internal affairs. ${ }^{19}$ As Coleman points out, "the charters of each colony had allowed the individual colonies to enact legislation that was 'suitable to their circumstances, not repugnant to, but as near might be agreeable to the laws of England.",20 This balance of dual sovereignty remained unquestioned until Parliament began interfering with the internal affairs of the colonies through the Sugar and Stamp Acts of 1764 and 1765. Outraged at Parliament's unprecedented exercise of power over internal colonial affairs, Americans cried "no taxation without representation" and defended the political liberty that they had enjoyed under the system of imperial federalism. In his 1774 "Novanglus" essays, John Adams addressed the disruption of this balance of power between Parliament and the colonies. Throughout these essays Adams undermined Parliament's power over the internal affairs of the colonies, writing:

We had considered ourselves as connected with Great Britain, but we never thought parliament the supreme legislature over us. We never generally supposed it to have any authority over us, but from necessity, and that necessity we thought confined to the regulation of trade, and to such matters as concerned all the colonies together. We never allowed them any authority in our internal concerns. ${ }^{21}$

This notion of colonial sovereignty only grew stronger as the Americans prepared for their secession from Great Britain. Coleman contends that "since colonial Americans had maintained that any authority England had over the colonies derived from colonial consent, the severing of their political bands from England meant this residual authority returned to the individual

\footnotetext{
${ }^{19}$ Aaron N. Coleman, "State Sovereignty, Interposition, and Liberty: The Constitutional Significance of Article II of the Articles of Confederation," (journal article, under review for publication, 2014), 5.

${ }^{20}$ Ibid., 6.

${ }^{21}$ John Adams, The Novanglus Essays, comp. The Federalist Papers Project, 30.
} 
colonies. ${ }^{22}$ And although the Declaration of Independence does not explicitly refer to the colonies as "sovereign," it nevertheless affirms that "these united colonies are, and of right ought to be, free and independent states" and that they reserve all the powers that free and independent states enjoy.

The sovereignty of the future states was further bolstered by their terms of separation from Great Britain. Harvard University and University of California, Berkeley professor Raoul Berger noted that each sovereign colony separately declared its independence from Great Britain. ${ }^{23}$ This was not a national effort. Berger also points out that, after the War for Independence had been won, the British Empire recognized the independent sovereignty of each state. In the 1783 Paris Peace Treaty between Great Britain and the United States, Britain “acknowledges the said United States, viz. New Hampshire, Massachusetts Bay, Rhode Island and Providence Plantations, Connecticut, New York, New Jersey, Pennsylvania, Maryland, Virginia, North Carolina, South Carolina and Georgia, to be free sovereign and independent states." 24

This principle of sovereignty was further perpetuated in the Articles of Confederation. Berger quotes several of our Founding Fathers who suggest that state sovereignty was widely accepted at the creation of the Articles. ${ }^{25}$ Oliver Ellsworth of Connecticut declared that "in the hour of common danger" the 13 states "associated as free and independent states." ${ }^{26}$ Jonathan Dayton of New Jersey confirmed that "[w]e, as distinct societies, entered into the compact (the

\footnotetext{
${ }^{22}$ Coleman, "State Sovereignty, Interposition, and Liberty," 11.

${ }^{23}$ Raoul Berger, Federalism: The Founders' Design, (Norman: University of Oklahoma Press, 1987 ), 35.

24 “The Definitive Treaty of Peace 1783," http://avalon.law.yale.edu/18th_century/paris.asp.

${ }^{25}$ Berger, Federalism, 30.

${ }^{26}$ Max Farrand, ed., The Records of the Federal Convention of 1787, (New Haven: Yale University Press, 1937), Vol. 1475.
} 
Articles of Confederation)." 27 And Luther Martin of Maryland asserted that "[a]t the separation from the British Empire, the people of America preferred the Establishment of themselves into thirteen separate sovereignties instead of incorporating themselves into one." ${ }^{28}$ Even the Articles themselves insisted that "each state retains its sovereignty, freedom, and independence, and every power, jurisdiction and right, which is not by this confederation expressly delegated to the United States, in Congress assembled." 29 And so, the historical context leading up to the eventual formation of a confederation among the former colonies, as well as the language of the Articles themselves, seem to suggest that the individual colonies/states possessed sovereign power. What, then, do the Articles of Confederation say about these questions?

\section{The Articles as Contract?}

During the War for Independence, the American colonies collectively recognized a need for some type of central government. No longer able to rely on Parliament to handle issues of foreign diplomacy, the colonies thought it prudent to create a central government that would manage the war, as well as international relations. And so John Dickinson of Delaware, a delegate to the Continental Congress, was charged with the task of constructing a confederation among the colonies and designing the proposed central government. After much debate on the structure and powers of this new government, the Continental Congress, composed of delegates from all thirteen colonies, agreed to the Articles of Confederation and Perpetual Union in

\footnotetext{
${ }^{27}$ Farrand, The Records of the Federal Convention of 1787, Vol. 1499.

${ }^{28}$ Ibid., Vol. 1 340-341.

${ }^{29}$ Articles of Confederation, Article II (1781).
} 
November of 1777 . The Articles created a "firm league of friendship" 30 between the thirteen colonies and established a central government with certain enumerated powers to conduct foreign affairs. The document was submitted to the colonies for ratification, with Maryland being the last colony to ratify the document in 1781. The Articles remained in operation until 1789 when the U.S. Constitution was adopted. ${ }^{31}$

The peculiar design of the Articles of Confederation has prompted many historians to question how the document should be understood. Based on the numerous references to the Articles as a contract, several scholars contend that the Articles can be understood in terms of Anglo-American contract law. In the Articles themselves, the agreement among the states is designated as a "confederacy"32 and a "confederation." "33 According to Samuel Johnson's 1785 dictionary, these terms denote "a league; a contract by which several persons or bodies of men engage to support each other; union; engagement; federal compact" ${ }^{\prime 34}$ (emphasis added). Records from the Constitutional Convention further imply that the Articles of Confederation were indeed a contract. James Madison specifically refers to the Articles as a "treaty... among the governments of independent states,"35 as well as a "confederation" and a "confederacy.",36

With regard to the parties in this compact, it is apparent that each colony/state, in its sovereign capacity, consented to this contract. Indeed, the preamble to the Articles reads: "the delegates of the United States of America....agree to certain articles of confederation and

\footnotetext{
${ }^{30}$ Articles of Confederation, Article III (1781).

31 “Articles of Confederation, 1777-1781," U.S. Department of State, Office of the Historian, accessed March 3, 2014, http://history.state.gov/milestones/1776-1783/articles.

${ }^{32}$ Articles of Confederation, Article I (1781).

${ }^{33}$ Articles of Confederation, Article II (1781).

${ }^{34}$ Samuel Johnson, A Dictionary of the English Language, (1785), accessed February 25, 2014, https://archive.org/details/dictionaryofeng101johnuoft, 447.

${ }^{35}$ Farrand, The Records of the Federal Convention of 1787, Vol. 1122.

${ }^{36}$ Ibid., Vol. 1 314-315.
} 
perpetual union between the states of New Hampshire, Massachusetts Bay, Rhode Island and Providence Plantations, Connecticut, New York, New Jersey, Pennsylvania, Delaware, Maryland, Virginia, North Carolina, South Carolina and Georgia." ${ }^{37}$ In reference to the Articles, William Paterson of New Jersey, a delegate to the Constitutional Convention, stated: "When independent societies confederate for mutual defence, they do so in their collective capacity; and then each state for those purposes must be considered as one of the contracting parties." ${ }^{, 38}$ Thus, evidence suggests that the Articles of Confederation can be considered a contract between sovereign states for their benefit and protection. This is especially significant to an understanding of the origins of American political theory. If the Articles of Confederation can be understood in terms of the compact theory and contract law, then a breach of contract would justify the annulment of the agreement in the eyes of the law. And eventually, at least according to James Madison, that is exactly what happened.

\section{Breach of Contract}

Although the Articles of Confederation stressed that "the union shall be perpetual," Union under the Articles was nevertheless deemed ineffective and a convention was called to improve it. Since the Articles did not provide the means for the dissolution of the established government, the members of the Convention spent a great deal of time at the 1787 Constitutional Convention discussing the proper way to break up the Union established by the Articles. During this lengthy discussion, James Madison asserted that "a breach of any one article, by any one

\footnotetext{
${ }^{37}$ Articles of Confederation, Preamble (1781).

${ }^{38}$ Farrand, The Records of the Federal Convention of 1787, Vol. 1259.

${ }^{39}$ Articles of Confederation, Article XIII (1781).
} 
party, leaves all the other parties at liberty, to consider the whole convention as dissolved." 40 Again, Madison stated that "[a]lthough all the states have assented to the confederation, an infraction of any one article by one of the states is a dissolution of the whole. This is the doctrine of the civil law on treaties. ${ }^{, 41}$ Madison, together with other delegates to the Constitutional Convention, argued that, because not all of the states strictly adhered to the Articles of Confederation and because the Articles were wholly ineffective, each state was free to sever its ties to the established Union. Thus, according to Madison, secession from the Union created by the Articles was permissible in the event of a breach of contract.

If the Articles of Confederation can legitimately be understood as a contract, can the same be said for their replacement, the U.S. Constitution?

\section{The U.S. Constitution: A Second Contract between the States?}

After several years of operating under the Articles of Confederation, it became apparent to the states that the Articles themselves were quite ineffective. There were several flaws with the system of government established under the Articles, including the prevalence of interstate trade issues, the absence of a national executive, and the lack of a national army, to name a few. After the central government's failed response to Shays' Rebellion in Massachusetts, the states were convinced that the Articles needed to be amended. And so, in the summer of 1787, the states sent delegates to a convention in Philadelphia to discuss changes to the Articles of Confederation. However, it turned out that, instead of just amending the Articles, the delegates agreed to replace them altogether with a new document, the United States Constitution. With the

\footnotetext{
${ }^{40}$ Farrand, The Records of the Federal Convention of 1787, Vol. 1315.

${ }^{41}$ Ibid., Vol. 1326.
} 
formulation of the Constitution, the delegates, in essence, dismantled the existing, "perpetual" Union "in order to form a more perfect union" 42 among the states.

How, then, should the Constitution be interpreted? Did the founders preserve the underlying principles of the Articles of Confederation in this "more perfect union," or did they build the new Union on a wholly new foundation? Are Americans justified in understanding the Constitution as a compact between the states, just like the Articles of Confederation? In order for this understanding of the Constitution to be considered plausible, the same three conditions of the compact theory must be met: the states must be considered sovereign political bodies, the founders must have recognized the Constitution as a contract, and the sovereign states must be the parties to this contract.

\section{Continued Sovereignty of the States}

The concept of state sovereignty was thoroughly entrenched in American political thought at our nation's inception. So, naturally, many delegates to the Constitutional Convention were worried about the proposed centralization of power in the new Constitution. The founders assured the delegates and their constituents that the sovereignty of the states would be well guarded. Writing under the pseudonym “Publius," James Madison, Alexander Hamilton, and John Jay did their best to allay these fears in their collection of essays called The Federalist Papers. Several of these essays offer insight into the concept of state sovereignty. In Federalist 35 Publius writes: "as the plan of the convention aims only at a partial union or consolidation, the state governments would clearly retain all the rights of sovereignty which they before had,

${ }^{42}$ U.S. Constitution, Preamble (1789). 
and which were not, by that act, exclusively delegated to the United States."43 Again in Federalist 39 Publius asserts that "[e]ach state, in ratifying the constitution, is considered as a sovereign body, independent of all others, and only to be bound by its own voluntary act."44 Furthermore, he assures the states in Federalist 45 that they "will retain, under the proposed constitution, a very extensive portion of active sovereignty...." important things. First, Publius concedes that the states were sovereign entities before the creation of the Union. He also acknowledges that the central government derives its power from the delegated sovereignty of the states. Note that these are two of the fundamental differences between the nationalist theory and the compact theory. It appears that Publius, despite his reputation as the main voice of centralizing Federalist defenders of the Constitution, offers significant evidence here in support of the compact theory of the Union.

Some states, still wary about the expansion of centralized power, took matters into their own hands to protect their sovereignty. Several state ratifying documents (specifically, Massachusetts, New Hampshire, Virginia, New York, and Rhode Island) explicitly declared that all powers not "clearly delegated" to the United States government were retained by the states. For example, the New York ratification document reads:

We, the delegates of the people of the state of New York...do declare and make known...that every power, jurisdiction, and right which is not by the said Constitution clearly delegated to the congress of the United States, or the departments thereof, remains to the people of the several states, or to their respective state governments, to whom they may have granted the same... ${ }^{46}$

\footnotetext{
43 Alexander Hamilton, John Jay, and James Madison, The Federalist, ed. by George W. Carey and James McClellan (Indianapolis: Liberty Fund, 2001), 155.

${ }^{44}$ Ibid., 197.

45 Ibid., 239.

${ }^{46}$ Jonathan Elliot, comp., Elliot's Debates (Philadelphia: J.B. Lippincott Company, 1941), Vol. 1327.
} 
The use of the term "delegate" is especially significant. It is the same word used in the $10^{\text {th }}$ Amendment to the Constitution, which reads: "The powers not delegated to the United States by the Constitution, nor prohibited by it to the States, are reserved to the States respectively, or to the people." The word "delegate" implies that the states are giving up some of their own sovereign powers and authorizing the central government to use those powers; that is, the central government only derives its power from the existing sovereignty of the states.

\section{The Constitution as Contract?}

In 1798 Thomas Jefferson and James Madison penned probably the most famous exposition of the compact theory of the 18th century: the Kentucky and Virginia Resolutions. These public documents were written and passed in response to the Adams' administration's Alien and Sedition Acts. They explicitly reference the Constitution as a "compact" a combined total of 16 times. Article I of the Kentucky Resolutions of 1798 reads:

Resolved, That the several States composing, the United States of America, are not united on the principle of unlimited submission to their general government; but that, by a compact under the style and title of a Constitution for the United States, and of amendments thereto, they constituted a general government for special purposes delegated to that government certain definite powers, reserving, each State to itself, the residuary mass of right to their own self-government; and that whensoever the general government assumes undelegated powers, its acts are unauthoritative, void, and of no force: that to this compact each State acceded as a State, and is an integral part, its coStates forming, as to itself, the other party: that the government created by this compact was not made the exclusive or final judge of the extent of the powers delegated to itself; since that would have made its discretion, and not the Constitution, the measure of its powers; but that, as in all other cases of compact among powers having no common 
judge, each party has an equal right to judge for itself, as well of infractions as of the mode and measure of redress. ${ }^{47}$

Likewise, the Virginia Resolutions of 1798 read:

[T]his Assembly doth explicitly and peremptorily declare, that it views the powers of the federal government, as resulting from the compact, to which the states are parties; as limited by the plain sense and intention of the instrument constituting the compact; as no further valid that they are authorized by the grants enumerated in that compact; and that in case of a deliberate, palpable, and dangerous exercise of other powers, not granted by the said compact, the states who are parties thereto, have the right, and are in duty bound, to interpose for arresting the progress of the evil, and for maintaining within their respective limits, the authorities, rights and liberties appertaining to them. ${ }^{48}$

Thomas Jefferson and James Madison, two of America's most prominent Founding Fathers, agreed that the Constitution was, in fact, a compact. But who were the parties to this compact?

The language of the Constitution itself offers an answer to this question. Here we also find some interesting evidence suggesting that the Constitution was a form of contract between the several states with the states maintaining their role as important political entities after its enactment.

Before a draft of the Constitution was referred to the Constitutional Convention's Committee of Style, the delegates to the convention agreed on the following text for the preamble: "We the People of the States of New Hampshire, Massachusetts, Rhode Island and Providence Plantations, Connecticut, New York, New Jersey, Pennsylvania, Delaware, Maryland, Virginia, North Carolina, South Carolina, and Georgia, do ordain, declare and establish the following Constitution for the Government of ourselves and our posterity." 49 Each state was named and identified as the unit within which the people's sovereignty was being

\footnotetext{
${ }^{47}$ Cited in William J. Watkins, Reclaiming the American Revolution: The Kentucky and Virginia Resolutions and Their Legacy (New York: Palgrave Macmillan, 2004), 165.

${ }^{48}$ Cited in Ibid., 170.

${ }^{49}$ Farrand, The Records of the Federal Convention of 1787, Vol. 2565.
} 
expressed. Uncertainty about which states would actually ratify the Constitution, however, prompted the Committee of Style to change the preamble to "We the People of the United States. ${ }^{, 50}$ While many nationalist theorists make much of this terminology, the history of the change seems to indicate it was done simply for the practical purpose that any nine states could have ratified the document and the Convention could not predict which they might be. Any state ratifying the document would be left out of the contract. As described in Article VII of the Constitution, the document is a "constitution between the States so ratifying the same."

Publius also addresses this issue in The Federalist Papers. Consistent with the language of the Constitution, he contends that the states are parties to this constitutional compact. $\mathrm{He}$ writes in Federalist 39 that the ratification of the Constitution "is to be given by the people, not as individuals composing one entire nation, but as composing the distinct and independent states to which they respectively belong. It is to be the assent and ratification of the several states, derived from the authority in each state...the authority of the people themselves. ${ }^{, 52}$ Furthermore, he asserts that ratification of the Constitution "must result from the unanimous consent of the several states that are parties to it." ${ }^{, 53}$

Additionally, James Madison himself asserts that the states are parties to the Constitution. Several delegates at the Virginia Ratifying Convention, like so many others, were concerned about the nature of the proposed government in the Constitution. Having just separated from the British Empire, they were worried about a strong central government that could quickly deteriorate into tyranny. One of the delegates, James Monroe, stressed his reservations

\footnotetext{
${ }^{50}$ Kenneth M. Stampp, "The Concept of a Perpetual Union," in The Imperiled Union: Essays on the Background of the Civil War (New York: Oxford University Press, 1980), 11.

${ }^{51}$ U.S. Constitution, Article VII (1789).

${ }^{52}$ Hamilton et al., The Federalist, 196.

${ }^{53}$ Ibid., 197.
} 
concerning the new Constitution: "Upon reviewing this government, I must say, under my present impression, I think it a dangerous government, and calculated to secure neither the interests nor the rights of our countrymen." ${ }^{, 54}$ Another delegate, Patrick Henry, warned the convention of the dangers of an overbearing federal government: "Here is a resolution as radical as that which separated us from Great Britain. It is radical in this transition; our rights and privileges are endangered, and the sovereignty of the states will be relinquished: and cannot we plainly see that this is actually the case?"55 To dispel the fears of Henry, Monroe, and others, Madison assured the delegates that the new government "is not completely consolidated, nor is it entirely federal." ${ }^{56}$ He says: "Who are the parties to it [the Constitution]? The people - but not the people as composing one great body; but the people as composing thirteen sovereignties." ${ }^{, 57}$ Furthermore, two of the ratifying instruments produced by these state conventions explicitly refer to the Constitution as compact between the states. The ratification documents of Massachusetts and New Hampshire acknowledge that the states are "entering into an explicit and solemn compact with each other..."58

\section{Breach of Contract}

What, then, happens if the terms agreed upon in the Constitution are violated? Recall that under Anglo-American contract law, aggrieved parties to the contract have the right to dissolve the compact and return to the status which they held before entering into the agreement. Several states explicitly asserted this right, insisting that their people had the right to recall the

\footnotetext{
${ }_{55}^{54}$ Elliot, Elliot's Debates, Vol. 3222.

${ }^{55}$ Ibid., Vol. 344.

${ }^{56}$ Ibid., Vol. 394.

${ }^{57}$ Ibid.

${ }^{58}$ Ibid., Vol. 1322.
} 
sovereignty which the state had delegated to the federal government. The Virginia ratification document states: "We, the delegates of the people of Virginia...do, in the name and in behalf of the people of Virginia, declare and make known, that the powers granted under the Constitution, being derived from the people of the United States, may be resumed by them, whensoever the same shall be perverted to their injury or oppression." 59 Similarly, New York's ratification document reads: "We, the delegates of the people of the State of New York...do declare and make known - That all the powers of government may be reassumed by the people whensoever it shall become necessary to their happiness." ${ }^{, 60}$ Following Virginia and New York's lead, Rhode Island's ratification document says:

We the delegates of the people of the Rhode Island and Providence Plantations...do declare and make known - That there are certain natural rights of which men, when they form a social compact, cannot deprive or divest of their posterity - among which are the enjoyment of life and liberty, with the means of acquiring, possessing, and protecting property, and pursuing and obtaining happiness and safety... That the powers of government may be reassumed by the people whensoever it shall become necessary to their happiness. ${ }^{61}$

Several prominent $19^{\text {th }}$ century statesmen read the history of the founding in similar ways, pointing to the Union as a compact that can be dissolved by one or more of the parties to that agreement. Frenchman Alexis de Tocqueville, celebrated for his classic work Democracy in America wrote:

The Union was formed by the voluntary agreement of the States; and in uniting together they have not forfeited their nationality, nor have they been reduced to the condition of one and the same people. If one of the States chooses to withdraw from the compact, it

\footnotetext{
${ }^{59}$ Elliot, Elliot's Debates, Vol. 1327.

${ }^{60}$ Ibid.

${ }^{61}$ Ibid., Vol. 1334.
} 
would be difficult to disprove its right of doing so, and the Federal Government would have no means of maintaining its claims directly either by force or right.",62

John Quincy Adams observed in 1839:

The indissoluble link of union between the people of the several states of this confederated nation is, after all, not in the right but in the heart. If the day should ever come (may Heaven avert it!) when the affections of the people of these States shall be alienated from each other; when the fraternal spirit shall give way to cold indifference, or collision of interests shall fester into hatred, the bands of political associations will not long hold together parties no longer attracted by the magnetism of conciliated interests and kindly sympathies; and far better will it be for the people of the disunited states to part in friendship from each other, than to be held together by constraint. Then will be the time for reverting to the precedents which occurred at the formation and adoption of the Constitution, to from again a more perfect Union by dissolving that which could no longer bind, and to leave the separated parts to be reunited by the law of political gravitation to the center. ${ }^{63}$

Likewise, President Jefferson wrote in 1803: "God bless them both [eastern and western states] and keep them in the union if it be for their good, but separate them if it be better. ${ }^{, 64}$ And again in 1816: "If any state in the Union will declare that it prefers separation...to continuance in union...I have no hesitation in saying, 'let us separate." "65 It appears that secession was a real and legitimate concern facing our new nation. Our founders could hope for the perpetuity of the Union, but this experiment in self-government was not certain to last forever.

\section{$\underline{\text { Conclusion }}$}

Many would agree that the question of disunion and secession in the United States was settled by the Civil War and, subsequently, in the Supreme Court's decision in Texas v. White

\footnotetext{
${ }^{62}$ Quoted in Livingston, "The Secession Tradition,” 12-13.

${ }^{63}$ Quoted in Ibid., 14.

${ }^{64}$ Thomas Jefferson, letter to John C. Breckinridge, August 12, 1803. Quoted in Stampp, "The Concept of a Perpetual Union," 24.

${ }^{65}$ Thomas Jefferson, letter to William H. Crawford, June 20, 1816. Quoted in Livingston, "The Founding and the Enlightenment," 259.
} 
(1869). In 1869 the Court declared: "The Constitution, in all its provisions, looks to an indestructible Union composed of indestructible States." ${ }^{\text {66 }}$ However, secessionist rhetoric did not die with the end of the Civil War and this ruling of the Supreme Court. Indeed, the secession debate is still alive and well in the United States as evidenced by several secession movements. For instance, in November 2012, the state of Texas submitted a secession petition to the White House website's "We the People" forum. ${ }^{67}$ The petition garnered over 125,000 signatures, prompting responses in the media and from the White House. And, lest it be assumed that secession is simply a southern concern, the state of Vermont has its own active secessionist movement. Founded in October 2003, the Second Vermont Republic is “a nonviolent citizens' network and think tank opposed to the tyranny of Wall Street, Corporate America, and the U.S. Government, and committed to the return of Vermont to its status as an independent republic and more broadly to the dissolution of the Empire." 68 One of the leading Vermont secessionists, former Duke University economics professor Thomas Naylor, argued that "the U.S. government has become too big, too centralized, too powerful, too undemocratic, too militaristic, too imperialistic, too materialistic, and too unresponsive to the needs of individual citizens and small communities." ${ }^{69}$ Naylor and other Vermont secessionists asserted that the United States is currently unsustainable and should be broken up into smaller regions that would be more responsive to citizens. Support for the movement has surged in Vermont and culminated in a

\footnotetext{
${ }^{66}$ Texas $v$. White, 74 U.S. 700 (1869).

67،We the People," last modified November 9, 2012, https://petitions.whitehouse.gov/petition/peacefully-grant-statetexas-withdraw-united-states-america-and-create-its-own-new-government/BmdWCP8B

${ }^{68}$ Rob Williams, "Most Likely to Secede: U.S. Empire and the Emerging Vermont Independence Effort," in Rethinking the American Union for the Twenty-First Century, ed. by Donald W. Livingston (Gretna: Pelican Publishing Company, 2012), 207.

${ }^{69}$ Ibid., 208.
} 
statewide secession convention held on October 28, 2005, the first of such conventions since North Carolina seceded from the Union in May of $1861 .^{70}$

Contemporary secession rhetoric like that from the Texas Nationalist Movement and the Second Vermont Republic is usually branded radical and ridiculous in mainstream media and politics. In response to the Texas secession petition, Mike Campbell, chief historian of the Texas State Historical Association, commented: "This is a strange phenomenon...Most of us sort of shake our heads." ${ }^{71}$ However, the evidence presented here raises enough questions about the nature of the American Union to shed new light on the legitimacy of secession. The evidence suggests that secession was a foundational principle from our country's very beginnings. Indeed, this nation was founded by the very act of sovereign states seceding from Great Britain. The Declaration of Independence itself can be viewed as a kind of secession petition that asserts a people's right to withdraw their consent to be governed, as well as their right "to institute new government" or "to throw off" government. As our founders shaped and molded our own fledgling Union, they incorporated the ideas of sovereignty and the contractual nature of government into our own political system. The sovereignty of the thirteen states and the consensual, contractual nature of the American Union can be seen in both the Articles of Confederation and the Constitution, as evidenced by their language and the debates surrounding their ratification. The Articles of Confederation forged a "league of friendship" and a "confederacy" between the thirteen states, which retained their "sovereignty, freedom, and independence." Likewise, the Constitution formed "a more perfect union... between the states so

\footnotetext{
${ }^{70}$ Williams, "Most Likely to Secede," 213.

${ }^{71}$ Kevin Cirilli, “Texans Blast Secession 'Tantrum,"” Politico, November 14, 2012 , http://www.politico.com/news/stories/1112/83859.html.
} 
ratifying the same." And although they hoped for a perpetual Union, many of our founders, including Thomas Jefferson and James Madison, accepted that secession was a legitimate and a very real possibility. John Quincy Adams famously said: “[I]f they will break us up - in God's name, let the Union go. I love the Union as I love my wife. But if my wife should ask and insist upon a separation, she should have it, though it broke my heart." ${ }^{, 72}$ Even Abraham Lincoln, the man who would become the greatest champion of the nationalist vision, professed the legitimacy of the dissolution of government at one point in his political career:

Any people anywhere, being inclined and having the power, have the right to rise up and shake off the existing government, and form a new one that suits them better. This is a most valuable, a most sacred right - a right which we hope and believe is to liberate the world. Nor is this right confined to cases in which the whole people of an existing government may choose to exercise it. Any portion of such people, that can, may revolutionize, and make their own of so much of the territory as they inhabit. ${ }^{73}$

Over the last two centuries, this understanding of the Union has become clouded with partisanship and covered with the dark history of America's most bloody and destructive war. Secession has become a "dirty word," inextricably linked "to the South, slavery and racism....,"74 As Jack Rakove has argued, however, no constitutional principle should be decided at the end of a bayonet. Despite their tattered reputation today, evidence from the founding period demonstrates that both the compact theory, and its remedy of last resort, secession, can find more legitimacy than we commonly assume in the founding vision of America.

\footnotetext{
${ }^{72}$ Quoted in Stampp, “The Concept of a Perpetual Union,” 24.

${ }^{73}$ Abraham Lincoln, Speech before the United States House of Representatives Concerning the War with Mexico, delivered January 12, 1848.

${ }^{74}$ Williams, "Most Likely to Secede," 196.
} 


\section{Bibliography}

Adams, John. The Novanglus Essays. Compiled by The Federalist Papers Project.

http://www.thefederalistpapers.org/wp-content/uploads/2012/12/The-Novanglus-Essaysy-John-Adams.pdf.

Berger, Raoul. Federalism: The Founders' Design. Norman: University of Oklahoma Press, 1987.

Bloch, Charles J. "The Shift from Colonies to States." In States' Rights - The Law of the Land, 10-25. Atlanta: The Harrison Company, 1958.

Brown, Kent Masterson. "Secession: A Constitutional Remedy that Protects Fundamental Liberties." In Rethinking the American Union for the Twenty-First Century, edited by Donald Livingston, 31-62. Gretna: Pelican Publishing Company, 2012.

Buchanan, Allen. Secession. Boulder: Westview Press, Inc., 1991.

Cheek, H. Lee. "Secession." In Encyclopedia of the American Civil War: A Political, Social, and Military History, edited by David S. Heidler and Jeanne T. Heidler, 1718-1720. Santa Barbara: W.W. Norton and Company, 2002.

Cirilli, Kevin. “Texans Blast Secession 'Tantrum.’” Politico. November 14, 2012. http://www.politico.com/news/stories/1112/83859.html.

Coleman, Aaron N. "State Sovereignty, Interposition, and Liberty: The Constitutional Significance of Article II of the Articles of Confederation." Journal article, under review for publication, 2014.

DiLorenzo, Thomas. "The Founding Fathers of Constitutional Subversion." In Rethinking the American Union for the Twenty-First Century, edited by Donald Livingston, 63-81. Gretna: Pelican Publishing Company, 2012.

Elliot, Jonathan, comp. Elliot's Debates. 2 ed. Philadelphia: J.B. Lippincott Company, 1941.

Farrand, Max, ed. The Records of the Federal Convention of 1787. Vol. 1-4. New Haven: Yale University Press, 1937.

Gordon, David. Introduction to Secession, State and Liberty, edited by David Gordon, ix-xvi. New Brunswick: Transaction Publishers, 1998.

Hamilton, Alexander, John Jay, and James Madison. The Federalist. Edited by George W. Carey and James McClellan. Gideon ed. Indianapolis: Liberty Fund, 2001.

Johnson, Samuel. A Dictionary of the English Language. London: 1785. Accessed February 25, 2014. https://archive.org/details/dictionaryofengl01johnuoft/. 
Livingston, Donald W. "The Founding and the Enlightenment." In Vital Remnants: America's Founding and the Western Tradition, edited by Gary L. Gregg II, 243-274. Wilmington: ISI Books, 1999.

Livingston, Donald W. "Introduction: The Old Assumptions No Longer Apply." In Rethinking the American Union for the Twenty-First Century, edited by Donald Livingston, 15-27. Gretna: Pelican Publishing Company, 2012.

Livingston, Donald W. "The Secession Tradition in America." In Secession, State and Liberty, edited by David Gordon, 1-33. New Brunswick: Transaction Publishers, 1998.

Nagel, Paul C. One Nation Indivisible. New York: Oxford University Press, 1964.

Neff, Stephen C. "Secession and Breach of Compact: The Law of Nature Meets the United States Constitution.” In Union and States' Rights: A History and Interpretation of Interposition, Nullification, and Secession 150 Years After Sumter, edited by Neil $\mathrm{H}$. Cogan, 88-110. Akron: University of Akron Press, 2014.

Rakove, Jack N. “'A Real Nondescript:’ James Madison's Thoughts on States’ Rights and Federalism." In Union and States' Rights: A History and Interpretation of Interposition, Nullification, and Secession 150 Years After Sumter, edited by Neil H. Cogan, 13-29. Akron: University of Akron Press, 2014.

Stampp, Kenneth M. "The Concept of a Perpetual Union." In The Imperiled Union: Essays on the Background of the Civil War, 3-36. New York: Oxford University Press, 1980.

Stromberg, Joseph R. "Republicanism, Federalism, and Secession in the South, 1790-1865." In Secession, State and Liberty, edited by David Gordon, 35-63. New Brunswick: Transaction Publishers, 1998.

Texas v. White, 74 U.S. 700 (1869).

U.S. Department of State, Office of the Historian. "Articles of Confederation, 1777-1781." Accessed March 3, 2014. http://history.state.gov/milestones/1776-1783/articles.

Watkins, William J. Reclaiming the American Revolution: The Kentucky and Virginia Resolutions and Their Legacy. New York: Palgrave Macmillan, 2004.

"We the People." Last modified November 9, 2012. https://petitions.whitehouse.gov/petition/peacefully-grant-state-texas-withdraw-unitedtates-america-and-create-its-own-new-government/BmdWCP8B

Williams, Rob. "Most Likely to Secede: U.S. Empire and the Emerging Vermont Independence Effort." In Rethinking the American Union for the Twenty-First Century, edited by Donald Livingston, 195-231. Gretna: Pelican Publishing Company, 2012. 
Yates, Steven. "When is Political Divorce Justified?" In Secession, State and Liberty, edited by David Gordon, 35-63. New Brunswick: Transaction Publishers, 1998. 